\title{
Tinjauan Bentuk Sediaan Farmasi Mengandung Peptida
}

\author{
Nur Selvia Yuswadinata*,1, Nasrul Wathoni² \\ ${ }^{1}$ Program Studi Sarjana, Fakultas Farmasi, Universitas Padjadjaran \\ 2Departemen Formulasi dan Teknologi Farmasi, Fakultas Farmasi, Universitas Padjadjaran \\ Jatinangor, 45363 \\ *E-mail: inurselviay@gmail.com \\ (Submit 10/12/2020, Revisi 1/1/2021, Diterima 1/5/2020, Terbit 1/6/2021)
}

\begin{abstract}
Abstrak
Peptida dan protein merupakan molekul yang memiliki fungsi vital dalam proses biokimia yang terjadi dalam tubuh. Peptida dan protein yang tidak adekuat dapat berpengaruh pada proses metabolisme dan berkaitan dengan kondisi patologis. Kemajuan ilmu pengetahuan dan teknologi membawa penemuan revolusioner dalam dunia medis yaitu menjadikan peptide dan protein sebagai terapi yang menjanjikan untuk pengobatan suatu penyakit. Penelitian di bidang farmasi terus berkembang untuk menemukan dan memproduksi berbagai sediaan farmasi dengan bahan aktif peptide dan protein. Masing-masing bentuk sediaan memiliki kelebihan dan kekurangan serta hambatan tersendiri pada rute administrasinya. Hal tersebut lebih lanjut dibahas pada review ini.
\end{abstract}

Kata kunci: peptida, protein, bentuk sediaan farmasi

\section{Pendahuluan}

Peptida dan protein merupakan molekul yang memiliki banyak fungsi vital terutama dalam segala proses biokimia yang terjadi di dalam tubuh. Beberapa contoh fungsi peptide dan protein adalah untuk reaksi katalisis ${ }^{(1)}$, sebagai transporter untuk proses keluar masuknya senyawa kimia pada sel(2).

Protein yang tidak adekuat dapat mempengaruhi proses yang terjadi dalam tubuh sebab protein memiliki fungsi sebagai enzim, pengatur pergerakan, pengatur sistem imun sehingga tubuh akan lebih mudah untuk terserang penyakit(3). Baik peptide dan protein juga terlibat dalam kondisi patologis seperti penyakit kanker, tekanan darah tinggi dan diabetes ${ }^{(4)}$.

Seiring berkembangnya zaman, ilmu pengetahuan dan teknologi mengalami kemajuan pesat sehingga memberi dampak pada pemahaman mengenai bidang biologi molekuler dan biokimia yang lebih baik. Penemuan-penemuan baru terkait peranan protein dalam tubuh dan kondisi patologis membawa peptida dan protein berpotensi besar untuk dikembangkan menjadi pilihan terapi dari berbagai jenis penyakit ${ }^{(5)}$. 
Lebih dari 100 protein terapeutik telah dimodifikasi dan disetujui oleh Uni Eropa dan Amerika yang kemudian digunakan untuk kepentingan klinis, dengan penjualan tertinggi sebesar $48 \%$ pada antibodi monoklonal(6).

\section{Struktur dan Sifat Peptida dan Protein}

Peptida dan protein tersusun atas asam amino yang saling berhubungan membentuk ikatan peptida. Asam amino tersusun oleh unsur hidrogen, karbon, nitrogen dan oksigen ${ }^{(3)}$. Di dalam asam amino terdapat gugus a-karboksil, a-amino serta gugus $\mathrm{R}$ yang melekat pada gugus a-karbon ${ }^{(7)}$.

Tabel 1. Jenis-Jenis Asam Amino(12)

\begin{tabular}{|c|c|}
\hline Jenis Asam Amino & Asam Amino \\
\hline Tirosin \\
\hline Serin \\
\hline Treonin \\
\hline Sistein \\
\hline Asam aspartat \\
\hline Asparagin \\
\hline Hidrofilik & Asam Glutamat \\
\hline Glutamin \\
\hline Lisin \\
\hline Arginin \\
\hline Hidrofobik & Hidin \\
\hline Glisin \\
\hline Alanin \\
\hline Valin \\
\hline Leusin \\
\hline
\end{tabular}


Urutan asam amino yang menyusun rantai peptida dan protein akan menentukan fungsi dan karakteristik spesifik protein yang dibentuknya ${ }^{(8)}$. Peptida dan protein terbentuk dari berbagai bentuk struktur. Terdapat empat bentuk struktur protein yaitu (1) struktur primer, (2) struktur sekunder, (3) struktur tersier dan (4) struktur kuartener (9).

Struktur primer, sekunder dan tersier akan membentuk rantai tunggal polipeptida ${ }^{(10)}$. Selain itu, peptida terbentuk dari susunan 3-70 asam amino(11). Struktur kuartener akan membentuk molekul protein yang kompleks dan berantai banyak melalui interaksi beberapa polipeptida(10). Jumlah asam amino, panjang rantai dan perbedaan struktur inilah yang membedakan peptida dan protein.

Asam amino yang menyusun peptida dan protein dapat dibagi menjadi dua kelas yaitu asam amino hidrofobik dan asam amino hidrofilik. Sifat ini diatur oleh rantai samping yang menyusun asam amino.

Kelarutan protein dalam air berbeda-beda, ada yang mudah larut dan ada yang sukar larut. Semua protein tidak bisa larut dalam pelarut organik yaitu kloroform, eter dan benzene. Protein merupakan molekul yang cukup mudah dipengaruhi oleh faktor fisik dan kimia sehingga mudah untuk mengalami denaturasi. Apabila protein telah terdenaturasi maka kelarutan dan aktivitas biologinya akan berubah. Penambahan garam pada suatu larutan yang mengandung protein dapat menyebabkan protein mengendap. Pemberian alkohol atau pemanasan juga akan menyebabkan protein menggumpal(13).

Selain sifatnya yang termolabil, protein juga bersifat amfoter. Pada $\mathrm{pH}$ rendah, gugus amino akan bereaksi dengan ion $\mathrm{H}+$ sehingga protein akan bermuatan positif. Pada kondisi $\mathrm{pH}$ tinggi, gugus karboksilat akan bereaksi dengan ion $\mathrm{OH}$ - dan menyebabkan protein bermuatan negatif(13). Karakteristik inilah yang menjadi tantangan dalam membuat sediaan farmasi dengan bahan aktif peptida dan protein.

\section{Sediaan Farmasi dengan Bahan aktif Peptida dan Protein}

Peran peptida dan protein yang terlibat dalam aktivitas biologi tubuh membuat keduanya sangat berpotensi dijadikan obat sebagai terapi suatu penyakit(14)(15). Selain digunakan sebagai agen terapi, peptida dan protein juga diaplikasikan dalam penegakkan diagnosis(16). Namun, dibalik pemanfaatan peptida dan protein sebagai agen terapi, masih ada banyak hal yang perlu diperhatikan dan dipertimbangkan terutama mengenai keamanan, imunogenisitas, efikasi, dan kualitasnya( ${ }^{(6)}$. Berikut disajikan beberapa contoh dari berbagai jenis bentuk sediaan farmasi dengan bahan aktif peptida dan protein yang sudah tersedia di pasaran terutama di Indonesia serta bagaimana permasalahan yang perlu dihadapi terkait bentuk sediaan dan rute administrasinya. 
Tabel 2. Beberapa Produk Obat dengan Bahan Aktif Peptida dan Protein yang Telah Beredar di Indonesia

\begin{tabular}{|c|c|c|c|c|}
\hline Sediaan & Peptida/Protein & Bentuk Sediaan & Nama Produk & Produksi oleh \\
\hline \multirow{8}{*}{ Liquid } & Insulin Aspart & Cairan Injeksi & Novorapid & Beta Pharmacon \\
\hline & $\begin{array}{c}\text { Poliomyelitis } \\
\text { Vaccine Inactivated }\end{array}$ & Suspensi & $\begin{array}{c}\text { Vaksin } \\
\text { Polomielitis Inaktif }\end{array}$ & Bio Farma \\
\hline & Poliovirus Vaccine & Drops & $\begin{array}{c}\text { Vaksin } \\
\text { Poliomielitis Oral }\end{array}$ & Bio Farma \\
\hline & $\begin{array}{c}\text { Diphteria Toxoid } \\
\text { Protein \& Tetanus } \\
\text { Toxoid }\end{array}$ & Cairan Injeksi & Vaksin Jerap Td & Bio Farma \\
\hline & Ciclosporin A & Larutan/Cairan & Cipol-N & $\begin{array}{c}\text { Otto } \\
\text { Pharmaceuticals } \\
\text { Inds }\end{array}$ \\
\hline & Trastuzumab & Cairan Injeksi & Herceptin & $\begin{array}{l}\text { Boehringer } \\
\text { Ingelheim }\end{array}$ \\
\hline & Liraglutide & Cairan Injeksi & Victoza & Beta Pharmacon \\
\hline & $\begin{array}{c}\text { Follicle Stimulating } \\
\text { Hormone }\end{array}$ & Cairan Injeksi & $\begin{array}{l}\text { Puregon } \\
50 \mathrm{IU} / 0,5 \mathrm{ml}\end{array}$ & $\begin{array}{l}\text { Merck Sharp \& } \\
\text { Dohme Pharma }\end{array}$ \\
\hline \multirow{3}{*}{ Solid } & Ciclosporin A & Kapsul Lunak & $\begin{array}{l}\text { Sandimmun } \\
\text { Neoral }\end{array}$ & Novartis Indonesia \\
\hline & Vedolizumab & Serbuk Injeksi & Entyvio & Takeda Indonesia \\
\hline & Growth Hormone & Serbuk Injeksi & $\begin{array}{l}\text { Genotropin } \\
\text { Goquick }\end{array}$ & Pfizer Indonesia \\
\hline
\end{tabular}

\section{Sediaan Solid}

Sediaan solid merupakan sediaan dengan bentuk serta tekstur yang padat dan kompak. Beberapa contohnya seperti tablet, kapsul, ovula dan supositoria(17). Sediaan solid menjadi sediaan paling banyak dipilih pada penggunaan peroral ${ }^{(18)}$. Meskipun umum dipilih, ada beberapa hal yang menjadi permasalahan utama apabila obat berbahan aktif peptida dan protein diberikan secara peroral.

Ukuran dan berat molekul yang besar, asam amino penyusun utamanya merupakan asam amino hidrofilik akan membuat peptida dan protein lebih sulit melewati membran biologis seperti mukosa gastrointestinal(19). Degradasi protein juga menjadi hambatan besar jika rute administrasinya adalah peroral. Hal ini disebabkan protein dan peptide dicerna oleh enzim proteolitik yang banyak terdapat pada saluran cerna ${ }^{(20)}$.

Namun, ada beberapa strategi yang dapat dilakukan untuk dapat meningkatkan stabilitas peptida dan protein jika dibuat dalam bentuk sediaan farmasi yang diadministrasikan secara peroral. 
Salah satunya adalah dengan modifikasi struktur seperti PEGylation, Glycosilation, Mannosylation (16), penambahan enzim inhibitor, absorption enhancer(21), GIT SiteSpecific Delivery, Membrane Transporters, Nanoparticles-Based Delivery System, Mucoadhesive Systems, Liposomes, dan Microspheres ${ }^{(1)}$.

Sediaan solid yang ada di Indonesia contohnya Ciclosporin A yang dibuat dalam bentuk mikroemulsi didesain menjadi kapsul lunak dikarenakan kelarutannya pada air sangat rendah. Formulasi baru Sandimmune Neoral menunjukkan peningkatan absorpsivitas dibandingkan dengan kapsul lunak formulasi sebelumnya ${ }^{(22)}$.

Sediaan lain seperti serbuk kering dengan rute nasal contohnya Exubera (insulin inhalasi) menjadi temuan terbaru sebagai solusi non-invasif untuk pasien. Penggunaannya yang lebih mudah dibandingkan insulin injeksi tidak memberi perbedaan pada efek samping kenaikan berat badan dan hipoglikemia. Hal yang perlu diperhatikan pada penggunaan secara inhalasi adalah bagaimana efek jangka panjang terhadap fungsi pernapasan. Data evaluasi fungsi pernapasan dari penggunaan Exubera masih sangat terbatas(23). Namun, penelitian menunjukkan pasien dengan asma dapat menurunkan absorpsi insulin inhalasi(24). Berbeda dengan kebiasaan merokok yang justru meningkatkan absorpsi insulin inhalasi hingga 3-4 kali lebih besar ${ }^{(25)}$.

\section{Sediaan Semisolid}

Sediaan semisolid umumnya digunakan dengan rute administrasi transdermal seperti salep, krim dan gel. Basis semisolid berfungsi sebagai penghantar zat aktif obat secara topikal melalui kulit, kornea, rektum, mukosa hidung, mukosa bukal dan membran uretra(26).

Keuntungan dari rute administrasi transdermal adalah tidak mengalami degradasi pada saluran cerna dan first-pass effect pada hati. Dengan rute transdermal dapat dibuat modifikasi seperti sustained release baik terapi sistemik maupun lokal sehingga jika ingin dihentikan dapat dengan mudah melepas alat dari kulit. Hal ini juga menjadi solusi dari singkatnya waktu paruh peptida dan protein dalam darah sehingga memerlukan dosis berulang yang apabila diadministrasikan secara parenteral bisa menimbulkan ketidaknyamanan pada pasien ${ }^{(27)}$.

Sampai saat ini, obat dengan bahan aktif peptida dan protein masih berkembang pada tahap penelitian. Salah satu penelitiannya adalah formulasi insulin dengan bentuk sediaan gel spray yang diadministrasikan secara intranasal pada kelinci. Hasilnya menunjukan absorpsivitas yang cepat telah menurunkan kadar gula darah yang cukup cepat pula dibandingkan dengan pemberian insulin intravena.

Bioavailabilitas dari insulin gel spray juga meningkat tiga kali lipat dibandingkan dengan larutan biasa. Penggunaan carbopol dalam formulasi ini berperan dalam meningkatkan absorpsivitas dengan mekanisme meningkatkan waktu kontak dan pembukaan sel epitel(28). 


\section{Sediaan Liquid}

Sediaan liquid adalah sediaan cair yang paling banyak dipilih dalam formulasi sediaan farmasi berbahan aktif peptide dan protein terutama antibodi monoklonal dan diadministrasikan secara parenteral baik intravena, subkutan, dan intramuskular(29). Kelebihan sediaan liquid yang diadministrasikan secara parenteral adalah terhindar dari proses absorpsi sehingga langsung terdistribusi di peredaran darah. Selain itu, peptida dan protein tidak akan mengalami degradasi oleh enzim proteolitik sebab tidak melalui sistem saluran cerna ${ }^{(30)}$.

Di samping kelebihannya, sediaan liquid memiliki kekurangan antara lain waktu paruh dari obat dengan zat aktif peptida dan protein yang singkat sehingga memerlukan beberapa kali administrasi. Administrasi berulang yang diberikan secara parenteral cukup membuat pasien tidak nyaman karena harus berkali-kali mendapatkan prosedur injeksi(31). Dintinjau dari stabilitasnya, sediaan liquid memiliki stabilitas lebih rendah dibandingkan dengan sediaan solid(29). Untuk obat-obat yang akan diadministrasikan secara parenteral namun tidak begitu stabil dalam bentuk larutan maka dibuat dalam bentuk serbuk injeksi. Serbuk injeksi perlu dilarutkan terlebih dahulu dengan pelarut seperti aqua pro injection, $\mathrm{NaCl} 0,9 \%$ dan dekstrosa $5 \%{ }^{(32)}$.

Vaksin poliomyelitis berisi virus polio hidup namun telah dilemahkan. Virus polio menginfeksi orofaring dan saluran cerna manusia melalui makanan atau sesuatu yang masuk ke dalam saluran cerna ${ }^{(33)}$. Vaksin ini dibuat dalam bentuk sediaan drops (tetes) yang diadministrasikan secara peroral dengan maksud supaya menimbulkan reaksi imun semirip mungkin dengan virus polio yang menginfeksi manusia (masuk ke saluran cerna).

\section{Kesimpulan}

Peptida dan protein telah dipilih sebagai alternatif terapi untuk berbagai jenis penyakit. Penelitian di bidang farmasi terus dilakukan untuk menemukan dan mengembangkan produk obat dengan bahan aktif peptida dan protein. Masing-masing bentuk sediaan memiliki kelebihan, kekurangan dan hambatan pada rute administrasinya. Perbaikan formulasi dengan melibatkan kemajuan teknologi telah diterapkan untuk meningkatkan efektivitas dan stabilitas produk.

\section{Daftar Pustaka}

1. Deb, Pran Kishore, et al. Protein/Peptide Drug Delivery Systems: Practical Consideration in Pharmaceutical Product Development. Basic Fundamental of Drug Delivery. s.I. : Elsevier, 2019, pp. 651-684.

2. Klasifikasi Fungsi Family Protein Transport Menggunakan Radial Basis Neural Network. Sandag, Green Arther and Kaunang, Fergie. 2, 2019, Cogito Smart Journal, Vol. 5, pp. 203-214.

3. Winarno, F. G. Kimia Pangan dan Gizi. Jakarta : Gramedia Pustaka Utama, 2004.

4. Voet, D and Voet, J. G. Amino Acid, Biochemistry. 4th. USA : Wiley, 2011. 
5. A Review On The Strategies For Oral Delivery Of Proteins And Peptides And Their Clinical Prospectives. Muheem, Abdul, et al. 4, 2016, Saudi Pharmaceutical Journal, Vol. 24, pp. 413-428.

6. Dimitrov, Dimiter S. Therapeutic Protein. [ed.] Vladimir Voynov and Justin A. Caravella. Therapeutic Proteins: Methods and Protocols. New Jersey : Humana Press, 2012, pp. 1-26.

7. Barasi, Mary E. At a Glance IImu Gizi. Jakarta : Erlangga, 2009.

8. Almatsier, Sunita. Prinsip Dasar IImu Gizi. Jakarta : Gramedia Pustaka Utama, 2001.

9. Vyas, S. P and Khar, K. R. Targeted and Controlled Drug Delivery: Novel Carrier System. New Delhi : CBS Publisher, 2002.

10. Pengaruh Protein Diet terhadap Indeks Glikemik. Probosari, Enny. 1, 2019, Journal Nutrition and Health, Vol. 7, pp. 33-39.

11. Protein Translocation Across the EUkaryotic Endoplasmic Reticulum and Bacterial Plasma Membranes. Rapoport, Tom A. 7170, 2007, Nature, Vol. 450, pp. 663-669.

12. Miller, Andrew and Tanner, Julian. Essentials of Chemical Biology. Chichester : John Wiley \& Sons, 2008.

13. Yazid, Estien and Nursanti, Lisda. Penuntun Praktikum Biokimia Untuk Mahasiswa Analis. Yogyakarta : C.V Andi Offset, 2006.

14. Wolf, Max and Ransberger, Karl. Enzyme-Therapy. New York : Vantage Press, 1972.

15. Holcenberg, J. S and Roberts, J. Enzymes as Drugs. New York : John Wiley \& Sons, 1981.

16. Joseph, Mary, Trinh, Hoang M. and Mitra, Ashim K. Peptide and Protein-Based Therapeutic Agents. Emerging Nanotechnologies for Diagnostics, Drug Delivery, and Medical Disease. s.I. : Elsevier, 2017, pp. 145-167.

17. Murtini, Gloria and Elisa, Yetri. Teknologi Sediaan Solid. Jakarta : Kementerian Kesehatan RI, 2018.

18. Sistem Penghantaran Obat Baru Peroral dengan Pelepasan Terkontrol. Indrawati, Teti. 1, 2011, Sainstech Farmas, Vol. 2, pp. 27-31.

19. Peptide Therapeutics: Current Status and Future Directions. Fosgerau, Keld and Hoffmann, Torsten. 2015, Drug Discovery Today, pp. 1-10.

20. Recent Developments in Protein and Peptide Parenteral Delivery Approaches. Patel, Ashaben, Cholkar, Kishore and Mitra, Ashim K. 3, 2014, Therapeutic Delivery, Vol. 5, pp. 337-365.

21. Basics and Recent Advances in Peptide and Protein Drug Delivery. Bruno, Benjamin J., Miller, Geoffrey D. and Lim, Carol S. 11, 2013, Therapeutic Delivery, Vol. 4, pp. 1443-1467.

22. Enhancement of the Oral Absorption of Cyclosporin in Man. Drewe, J, et al. 1, 1992, British Journal of Clinical Pharmacology, Vol. 34, pp. 60-64.

23. Exubera (Inhaled Insulin): an Evidence-Based Review of Its Effectiveness in the Management of Diabetes. Profit, Louise. 2, 2005, Core Evidence, Vol. 1, pp. 89-101.

24. Inhaled Insulin Using the AERx Insulin Diabetes Management System in Healthy and ASthmatic Subjects. Henry, Robert R, et al. 3, 2003, Diabetes Care, Vol. 26, pp. 746-749.

25. The Effect of Smoking Cessation and Subsequent Resumption on Absorption of Inhaled Insulin. Becker, Reinhard H. A, et al. 2, 2006, Emerging Treatments and Technologies, Vol. 29, pp. 277-282. 
26. A Review on Penentration Enhancer for Semisolids. Sonje, Abhijit, et al. 5, 2013, Asian Journal of Pharmaceutical Research and Development, Vol. 1, pp. 94-107.

27. Transdermal Delivery of Peptide and Protein Drugs: an Overview. Amsden, B. G and Goosen, M. F. A. 8, 1995, Bioengineering, Food and Natural Products, Vol. 41, pp. 1972-1997.

28. Intranasal Bioavailability of Insuline from Carbopol-Based Gel Spray in Rabbits.

Najafabadi, Abdolhossein Rouholamini, Moslemi, Payam and Tajerzadeh, Hosnieh.

5, 2004, Drug Delivery, Vol. 11, pp. 295-300.

29. Shire, Steven J. Formulation of Protein and Monoclonal Antibodies (mAbs). Monoclonal Antibodies. Cambridge : Woodhead Publishing, 2015, pp. 93-120.

30. Novel Delivery Technologies for Protein and Peptide Therapeutics. Kumar, T. R. S, Soppimath, K. and Nachaegari, S. K. 4, 2006, Current Pharmaceutical Biotechnology, Vol. 7, pp. 261-276.

31. Long-Term Delivery of Protein Therapeutics. Vaishya, Ravi, et al. 3, 2015, Expert Opinion on Drug Delivery, Vol. 12, pp. 415-440.

32. Trissel, L. A. Handbook on Injectable Drugs 17th Ed. Bethesda : ASHP, 2013.

33. Poliovirus, Pathogenesis of Poliomyelitis, and Apoptosis. Blondel, B., et al. 2005, Current Topics in Microbiology and Immunology, Vol. 289, pp. 25-56. 